\title{
Micro Finance, Women Empowerment, Livelihood Initiatives and Problems Faced - A Study W.R.T. Bengaluru Urban
}

\author{
Sunitha Y.K' Lakshmi Priya M C ${ }^{2}$ and Rajimol K P3 \\ ${ }^{1}$ Department of Master of Business Administration, Sri Venkateshwara \\ College of Engineering, Bengaluru, India \\ ${ }^{2}$ Department of Master of Business Administration, SJB Institute of Technology, Bengaluru, India \\ ${ }^{3}$ Atria Centre for Management and Entrepreneurship, Atria Institute of Technology, Bengaluru, India
}

\section{ABSTRACT}

This paper examines the effect of urban microfinance on occupation and problems encountered by microfinance actions. The survey through a questionnaire is made on a total of 100 sample respondents locating in the outskirts and slum areas of Bengaluru urban. It is been found that urban microfinance has a statistically trivial positive impact on some income or expenditure variables. Urban microfinance is becoming popular since the urban poor like rural poor also wanted to gain the benefits of microfinance activities. Self Help Groups (SHGs) are deemed to be the most important tools in participation of approach for the socio-economic development of women. Several previous studies have been proved that SHs programmes fall under the type of schemes and savings of micro credit. It has been successful in shifting the life of underprivileged women through enhancement of income and self esteem (Rigin, 2014). It is been observed that there is been a greater association between the attributes under study.

\section{KEY WORDS: COVID-19, DOMESTICS VIOLENCE, EMPOWERMENT, RELATIONSHIP, SELF ESTEEM.}

\section{INTRODUCTION}

Equal allocation of monetary growth among poor, deserved and susceptible in the society is presuming significance. Professionals in the area of developmental economies are constantly stressing the requirement of appraising financial inclusion for growth (Dadhich, 2011). Microfinance is a popular programme which improvises the living standards of either urban poor or rural poor. The importance of micro finance emerges basically on account of failure on the part of formal financial agencies in meeting the needs of poor. Women across the globe

\section{ARTICLE INFORMATION}

*Corresponding Author: sunithayk@gmail.com

Received 11th Oct 2020 Accepted after revision 27th Dec 2020

Print ISSN: 0974-6455 Online ISSN: 2321-4007 CODEN: BBRCBA

Thomson Reuters ISI Web of Science Clarivate Analytics USA and Crossref Indexed Journal

\section{Clarivate
Analytics}

NAAS Journal Score 2020 (4.31)

A Society of Science and Nature Publication,

Bhopal India 2020. All rights reserved.

Online Contents Available at: http//www.bbrc.in/

Doi: $h t t p: / / d x$.doi.org/10.21786/bbrc/13.13/32 represent $50 \%$ of population, but women get their due rights in no country including developed countries (Pujari, 2012).

It is a very well acknowledged fact that women are considered to be the paramount strategem to surmount all difficulties faced by urban deprived women. Empowerment brings changes in thoughts and observations and opens the door for self development among the urban poor women. Microfinance is observed as protection against unanticipated status in the financial cycle of the movement of poor people (Santhosh, 2012). Tessi Swope, (2005) articulated clearly that the advantage of higher education, decrease in susceptibility to economic shock and larger empowerment is been enjoyed by the participants in microfinance initiatives. Women empowerment is considered as a best strategy to lessen gender unfairness and to exclude the entire earnings of the day landing over to the male head of the family. 


\section{MATERIAL AND METHODS}

Review of Literature: Microfinance has been demonstrated to be a tool to reduce poverty level from the face of earth. Further, it has been stated that in the past 2 decades it has appeared as an industry to meet to the financial needs of the poor whom banks have turned down due to lack of guarantee (Amarjeet Kaur Malhotra, et al., 2017). It is essential to employ microcredit as it is the basis of empowerment of the underpriviliged women both in villages and cities of Indian states. The study was undertaken for a period from 2007 to 2014, based on a group of the Indian states, and have been investigated the effect of women empowerment through various women Self Help Groups and women employment opportunities. They have observed that both are corresponding to each other. Further, it is been noticed that changes in per capita earnings and poverty rate has persuaded the possibility for women employment and outreach of women SHGs across the Indian states. Factors like increasing accessibility to bank credits and women education have helped to advance the women empowerment drive (Deviprasad DASH et al., 2017).

In a study conducted to evaluate the effect of micro credit on women empowerment, a Paired $t$ - test has been used to analyze the joining of women for SHGs before and after for the empowerment on three angles, that is, political, social, and economic on 12 variables. It is been found out from the test a major difference in women empowerment pointers before and after joining SHGs. The results of binary logistic regression showed that with the increase in length of membership by 1 year, the probability of empowering women on the basis of economic, social, and political empowerment increased by 9 percent, 14 percent, and 11 percent. They also have stated that the study can be used to empower women on the grounds of political, social, and economic conditions. If the microfinance is implemented successfully it could lead to societal change in rural areas, especially in the country like India. It was suggested that the government and non-government organizations (NGOs) can work on microfinance services to empower women(Nikumj Patel et al.,2017).

Along with lack of proven impact of micro credit specifically in India, Bangladesh and Mexico has been criticized for higher interest rate, usage of credits for own utilization, the creation of debt traps for the poor, sometimes awful effects of extreme pressure for respondent from loan officers or loan groups (Roodman 2012). Availability of micro loans can make positive conditions for psychological or social funding to improve financial conditions(Alexander Newman 2014). As the access to microfinance has increased it has more likely lead to higher probability of economic as well as social empowerment. The importance of such relationship is dependent on marital status and education but not dependent on age (Bismark Addai, 2017).

Accessibility of credit through micro finance Companies has a positive effect on social empowerment of women and also utilization of credit by woman itself is important(Khan \&t Noreen, 2012). If we want women to be empowered, it means currently they are mot empowered, deprived by the way power relations shape their choices, opportunities and their well being (Mosedale, 2005). It shows 13.2\% association of women with micro finance is empowered through composite indicator. The duration of membership in SHGs increases the frequency of women's economic and political empowerment, but it does not show a momentous relationship with their social empowerment. Social and political empowerment necessarily may not be relied on economic empowerment. (Sahu G B, 2015).

It is well thought that microfinance is one of the financial assistance in many countries. It is preferred to reduce the level of poverty. It is been observed from a regression analysis which based on four factors derived from factor analysis which shows improvement of monthly earning and expenditure that contributed the most. Whereas personality development contributed to the least to the improvement of economic and social status of women (Patel R et al., 2018). Cultural are the important obstacles to female education. Some culture do not allow the education of women and girls and they do not provide the opportunity to succeed through education (Reema P Basheer, 2018).

According to one of the communities (GMCL) which is run by female untouchable members in the urban sector, shows that it enriches productive capabilities of women, management skills and to some extent social learning capabilities but fails in achieving marginalization resulting from issues of caste embedded in established patriarchal norms and practices (Martnez A et al., 2014). Microfinance products are available in different categories with distinctive characteristics. Each product has associated benefits to the communities. Most vulnerable community is financially weak. Microfinance helps to diminish exposure of risk by poor through income smoothing, while saving can help them recover from the losses of disaster (Khan M et al., 2017).

Micro credits are efficient strategic tools for poverty mitigation only if it is used for micro enterprise development by income generation. Since the members of SHGs belong to deprived and weaker sections of the country, the future and endurance of SHGs ultimately depends on their progress towards microenterprise development for generating income to improve the standard of living of its members (Suprabha K R 2014)

Need For The Study: Thousands of people in Bengaluru are dependent on daily wages and are street vendors. COVID 19 pandemic has hit the life of thousands of people in urban areas of Bengaluru. Many people wandered from the city to their native places. This is so because they strived with hunger due to loss of jobs and hampered their small businesses. Keeping this in mind, a study was planned to undertake to rebuild the lives of poor and economically backward class of people. 


\section{Objectives of the Study}

1. To study the demographic profile of respondents.

2. To analyse the areas of improvement empowerment.

3. To analyse the livelihood activities undertaken by respondents.

4. To analyse the dominant factors leading to problems.

Figure 1: Socio-economic characteristics and level of awareness: Chi-square and contingency coefficient.

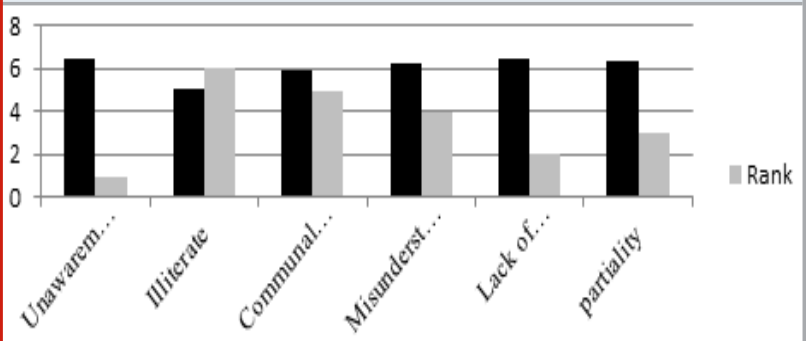

Source: Authors compilation

Note: $x^{2}=$ Chi-square

"C" = Sq.Rt. $\left[\left(\mathrm{x}^{2} / \mathrm{x}^{2}+\mathrm{N}\right)\right]$

Where $\mathrm{c}=$ Contingency co-efficient

$\mathrm{X}^{2}=$ Chi-square calculated value

$\mathrm{N}=$ Number of observation

When the value of ' $c$ ' is equal or nearer one, it means there is high degree of association between its attributes.

Contingency co-efficient will always be less than 1 .

\section{Hypotheses}

1. The demographic profile study of respondents is not supporting the study.

2. There are no areas of empowerment improvement.

3. There are no livelihood activities undertaken by the women respondents.

4. Dominant factors are not leading to problems.

Research Methodology: It is descriptive study. Only data through survey has been used for studying the objectives. Data has been collected through a well drafted questionnaire. The researcher has approached the self help groups in Bengaluru urban area of outskirts and slum. The sample size limited to 100 due to outbreak of Covid-19 pandemic. For analysis of the study weighted average, Chi-square coefficient of contingency and Henry Garrett ranking techniques are applied. The study is only confined to Bengaluru and outer skirts and such as visited for the purpose of data collection. Social distance, transportation problems are faced even at the time of recovery stage after removal of norms of lockdown.

\section{RESULTS AND DISCUSSION}

Survey Findings: Figure - 1 highlights data about socioeconomic profile of respondents. Based on the table- 1 it can be clearly inferred that there is a significant relation between the attributes. Further, the table also reveals that there exists high degree of association or relationship between the attributes except the living conditions. Table - 2 reveals the data about the socio-economic empowerment of women respondents after joining the Self help groups. The weighted average technique has been performed. Likert's 5 point scale is used for expression of opinions by respondents. It has used the range such as strongly agree, agree neutral, disagree and strongly disagree and weights are assigned in the manner of $5,4,3,2$, \& 1 .

Table-2 \& 3 reveals that 31 score is assigned to economic independence and micro savings formation followed by 30 score is assigned to freedom from violence, smooth public relation and breaking social cultural factors, 29 score is assigned to increased self reliance and 28, 27 and 25 score is assigned to improvement in standard of living, jewellery, land purchases and house construction. From the above analysis economic independence and macro savings formation places a first area of performance and followed second area by freedom from domestic violence, smooth public relation and breaking social, cultural factors and third area by increased self reliance.

\begin{tabular}{|l|c|c|c|c|c|c|}
\hline Table 1. Socio-economic empowerment after joining SHGs - using weighted average \\
\hline Areas improved & SA & A & N & DA & SDA & Total \\
\hline 1. Economic independence & 70 & 20 & 10 & - & - & 100 \\
\hline 2. Increased self reliance & 58 & 22 & 15 & 5 & - & 100 \\
\hline 3. Improvement in standard of living & 62 & 15 & 14 & 4 & 5 & 100 \\
\hline 4. Freedom from domestic violence & 71 & 12 & 9 & 6 & 2 & 100 \\
\hline 5. Smooth public relations ft participation & 65 & 28 & 3 & 2 & 2 & 120 \\
\hline 6. Decision making in households & 25 & 30 & 22 & 15 & 8 & 100 \\
\hline 7. Breaking social, cultural factors & 79 & 9 & 4 & 5 & 3 & 100 \\
\hline 8. Micro savings formation & 80 & 8 & 6 & 4 & 2 & 100 \\
\hline 9. Jewellery, land purchasers \&t house constructions & 60 & 10 & 15 & 8 & 7 & 100 \\
\hline 10. Leadership quality & 35 & 30 & 18 & 9 & 8 & 100 \\
\hline
\end{tabular}

Source: Authors compilation 
Table 2. Weighted average (WA) analysis

Areas improved

1. Economic independence

2. Increased self reliance

3. Improvement in standard of living

4. Freedom from domestic violence

5. Smooth public relations \&t participation

6. Decision making in households

7. Breaking social, cultural factors

8. Micro savings formation

9. Jewellery, land purchasers \&t house constructions

10. Leadership quality

Source Authors compilation

Figure 2: Livelihood activities - Garrett ranking technique

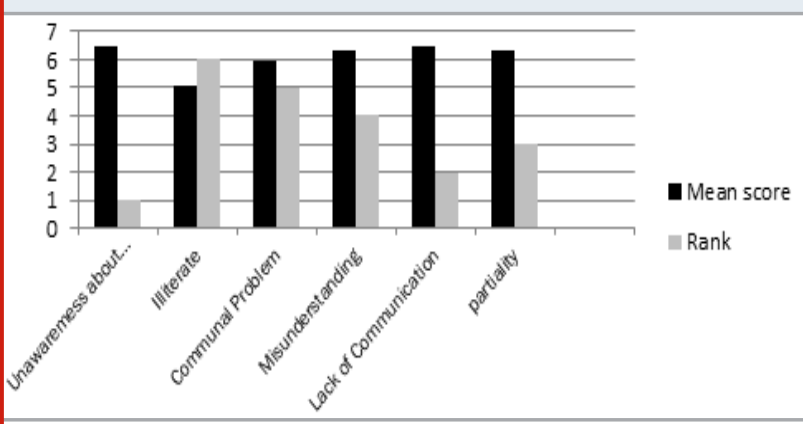

Source: Authors compilation

Note : $\mathrm{x}$ - Scale value; $\mathrm{f}$ - Number of customers

fx - Score value; $\quad \mathrm{R}$ - Ranks

For Garrett values refer to Garrett rank conversion table.

Figure 6: Dominant factor leads to problems - Garrett ranking technique

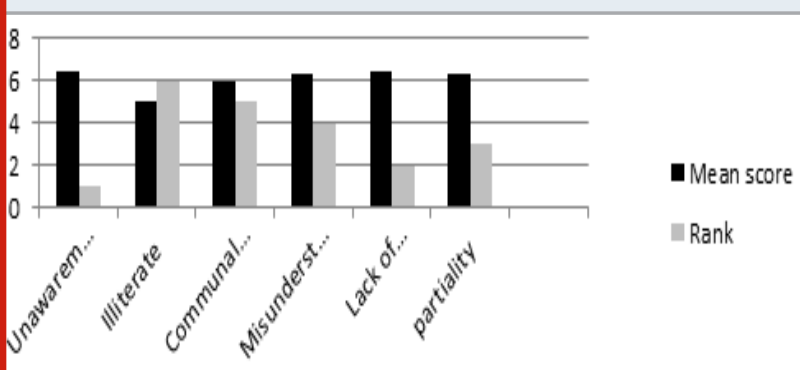

Note : $\mathrm{x}$ - Scale value; $\mathrm{f}$ - Number of customers

fx - Score value; $\quad \mathrm{R}$ - Ranks

For Garrett values refer to Garrett rank conversion table.

Figure - 4 reports about livelihood activities of women SHG members using Garrett ranking technique. Garrett ranking tool was used to ascertain the respondents' tasking of rank for occupation by women in the
Table 3. Per cent Position and Garrett values

\begin{tabular}{|l|c|c|c|}
\hline Sl.No. & $\begin{array}{c}100\left(\mathrm{R}_{\mathrm{ij}}-\right. \\
\mathbf{0 . 5}) / \mathrm{N}_{\mathrm{j}}\end{array}$ & $\begin{array}{c}\text { Calculated } \\
\text { value }\end{array}$ & $\begin{array}{c}\text { Garrett } \\
\text { Value }\end{array}$ \\
\hline 1. & $100(1-0.5) / 7$ & 7.14 & 78 \\
\hline 2. & $100(2-0.5) / 7$ & 21.42 & 66 \\
\hline 3. & $100(3-0.5) / 7$ & 35.71 & 57 \\
\hline 4. & $100(4-0.5) / 7$ & 50.00 & 50 \\
\hline 5. & $100(5-0.5) / 7$ & 64.28 & 43 \\
\hline 6. & $100(6-0.5) / 7$ & 78.57 & 35 \\
\hline 7. & $100(7-0.5) / 7$ & 92.85 & 22 \\
\hline
\end{tabular}

Source: Dhanavandan, S. (2016). Application of Garrett ranking technique. Practical approach, International journal of library and information studies, 6(3), 135-140.

Table 4. Per cent Position and Garrett values

\begin{tabular}{|l|c|c|c|}
\hline Sl.No. & $\begin{array}{c}100\left(\mathrm{R}_{\mathrm{ij}}-\right. \\
0.5) / \mathrm{N}_{\mathrm{j}}\end{array}$ & $\begin{array}{c}\text { Calculated } \\
\text { value }\end{array}$ & $\begin{array}{c}\text { Garrett } \\
\text { Value }\end{array}$ \\
\hline 1. & $100(1-0.5) / 6$ & 8.33 & 77 \\
\hline 2. & $100(2-0.5) / 6$ & 25.00 & 63 \\
\hline 3. & $100(3-0.5) / 6$ & 41.67 & 54 \\
\hline 4. & $100(4-0.5) / 6$ & 58.33 & 46 \\
\hline 5. & $100(5-0.5) / 6$ & 75.00 & 37 \\
\hline 6. & $100(6-0.5) / 6$ & 91.67 & 23 \\
\hline
\end{tabular}

Source: Dhanavandan, S. (2016). Application of Garrett ranking technique. Practical approach, International journal of library and information studies, 6(3), 135-140.

organization of SHGs. Ranking awarded by respondents for each occupation is combined. The tasked ranks by the respondents were transformed into percentage (table-5) using the relevant formula. For each percentage position, 
using Garrett's conversion table, the Garett value is obtained. The relevant formula is also stated in the table-5. Aggregate of the score is worked out for each rank column and mean scores are calculated by dividing the total score by the number of observations. Finally, depending upon the strengths of mean score ranks are assigned. It is observed from the figure first rank was assigned to construction work followed by second rank was given to caring the children and third rank was assigned to push cart vegetable selling and the final rank was assigned to meat merchant.

Figure-6 highlights data about dominant factors leading to problems which vary from unawareness to partially. Based on the strength of mean score first rank was assigned to unawareness about SHG activities with mean score 64.65 followed by second rank lack of communication with 64.39 means score, third rank was assigned to partiality. Percent position is given in Table-7 and Garrett values are shown in the last column which are derived by referring to the Garrett ranking conversion table.

\section{CONCLUSION}

A microfinance initiative at Bengaluru urban area has impacted very much and innumerable urban poor has been benefited. Though it is proven successive but yet the SHGs are facing some problems which can be alleviated through proper education. The SHGs are highly successful in the areas of handicrafts and other novelties selling at local, national fairs. Some of the SHGs are supplying provisions to the door steps. The SHG members at Bengaluru are successful in mobilizing small amount of money and lend at agreeable interest rates. What is needed now is that the members require proper awareness creation through education. Successful implementation could definitely helps in social transformation in rural part of the country. Government and non-government organizations should look at working out amicable rates of interest so that large part of urban poor can avail greater benefits.

\section{REFERENCES}

Alexander Newman Susan Schwarz \&t David Borgia. (2014). How does MF enhance entrepreneurial outcomes in emerging economies? The mediating mechanism of psychological and social capital International small Business journal 32(2) 168.

Bismark Addai(2017), Women empowerment through Micro Finance, Empirical Evidence from Ghana, Journal of Finance and Accounting, Science Publishing Group 5(1) 1-11.

Dadhich C L (2011) MF - A panacea for poverty alleviation. A case study of oriental Grameen Project in India Indian Journal of Agricultural Economies 56(3) 421-427.

Emerald Publishing Limited (2017) Raji AjwaniRamchandani The Role of Microfinance in Women's Empowerment, A Comparative Study of Rural \& Urban Groups in India 25-45
Mathur P \& Agarwal, P(2017). Self-help groups: a seed for intrinsic empowerment of Indian rural women. Equality, Diversity and Inclusion: An International Journal 36 (2) 182 - 196.

Mosedale, S. Policy arena Assessing women's empowerment: Towards a conceptual framework (2005). Journal of International Development 17, 243-257

Patel R, Patel M \& Patel N (2018) Impact of microfinance on poor women: Lessons from North Gujarat Prabandhan: Indian Journal of Management, 11(2) 14-29

Patel, R., \&t Patel, N. (2017) Social and economic impact of microfinance on urban poor women: An empirical study of Ahmedabad city (India). IIMS Journal of Management Science 8 (2) 110 - 121.

Pujari MD (2012) Women Empowerment in India. Online International Inter Disciplinary Research Journal. 11(11) 210.

Ritesh Patel, Mitesh Patel, Nikunj Patel(2018) Impact of Micro Finance on Women Empowerment A Study of Rural Gujarat Indian Journal of Finance Vol.12-8 35-42

Roodman D (2012) Due diligence An Impartment Inquiry Indo Microfinance Washington, DC Centre for global development.

Rigin E.V \& Geetharani K (2014) An analysis of factors influencing women empowerment by SHGs Sivakasi Pezzottaite Journals 3(2) 891-897.

Reema P Basheer: Empowerment of Women through Education: A Special Reference to Mahathma Gandhi: 5(3) 1756-1758.

S.SARAVANAN Devi Prasad DASH (2017) Micro finance And Women Empowerment Empirical Evidence from Indian States Regional and Sectoral Economic Studies 17(2) 69-78.

Sahu, G. B. (2015). How effective is a self-help group led microfinance programme in empowering women? Evidence from rural India 50(5) 542-548

Sharma, P. P., \&t Pati, A. P. (2015). Subsidized microfinance and sustainability of self-help groups (SHGs): Observations from North East India. Indian Journal of Finance, 9(5), 7-19

Suprabha, K. R. (2014). Empowerment of self-help groups (SHGs) towards microenterprise development. Procedia Economics and Finance, 11(7), 410-422

Santhosh Sadar (2012) MF programmes for poverty alleviation Pravana Management Reviews 11(2) 21.

Torri, M. C., \& Martinez, A. (2014). Women's empowerment and micro-entrepreneurship in India: Constructing a new development paradigm? Progress in Development Studies, 14(1), 31-48

Ullah I, \&t Khan, M (2017) Microfinance as a tool for developing resilience in vulnerable communities. Journal of Enterprising Communities: People and Places in the Global Economy, 11(2), 237 - 257

Vijaykumar N V, \& Naidu, G. J. (2016). Does microfinance training enhance the financial literacy among members of self help groups? Indian Journal of Finance, 10 (7) $22-33$. 